\title{
Regulatory framework of strike and its problem in Latvia
}

\author{
Kitija Bite
}

Rīga Stradiņš University, Faculty of Law, Riga, Latvia

\begin{abstract}
International legal provisions provide for human rights and freedoms, and the freedom of expression and the right to work belong to these. Considering that during any employment relationship disputes can arise between the involved parties, international legal provisions state that a strike as the final means for the settlement of a dispute can be used. Paragraph 108 of the Satversme (the Constitution of Latvia) provides that in Latvia, employed people have the right to strike. Systematically, the provisions of the Constitution are being regulated by the Labour Dispute Law and the Strike Law. It might seem that in Latvia, any employed person has been entitled to the right to strike as provided by the Satversme. However, the strike of general practitioners in summer 2017 highlighted the problem of executing strikes. Firstly, at the time being, the right to strike can only be associated with one form of employment, i.e., employment relationship. As only a part of general practitioners is employed on the basis of an employment agreement, the strike regulatory framework that is in force in Latvia can be used only by a part of general practitioners employed under an employment agreement in order to protect their collective interests. Secondly, the Labour Dispute Law provides for that a strike as the final means can be used exclusively for the protection of collective interests (within the framework of concluding a collective agreement), but not within the framework of a contract governed by public law. The strike by general practitioners showed that Latvia has complied only partially with international legal provisions because a strike can only be used by people employed under employment agreements and only in disagreements regarding a Collective agreement. In order to resolve this problem so that any employed person is entitled to the right to strike in the future, it is necessary to amend the Labour Dispute Law by expanding the range of labour dispute subjects. The aim: to analyse international and Latvia's regulatory framework for the right of employed people to strike and recommend necessary amendments to laws to solve detected problems. Materials used: international legal provisions and Latvian legal acts, publications and literature. Methods used in this article: descriptive, analysis, synthesis, dogmatic, induction and deduction as well as legal interpretation methods grammatical, systemic, historical and teleological.
\end{abstract}

Key words: labour dispute, strike, employment, strike of general practitioners, employment agreement, collective agreement.

\section{Right to strike for employed people}

The natural privilege by an individual is not only limited as to undertake any action for himself or herself and to be on their own, but also it is an ability to adjust their activities to their peers and combine their efforts with the efforts of their peers and to work together. Thus, the importance of the freedom of association with other peers is highlighted by the fact 
that the freedom of thought, opinion, and expression would be of low significance if it does not grant any opportunity to express thoughts, ideas, beliefs and views to their peers who have unified due to similar grounds and aims $[1,4]$.

The right to express his or her views and to protect legal interests in a democratic society belong to human rights, i.e., they belong to civil and political rights. In Latvia, these rights are included in several legal provisions of the Constitution: the right to freedom of expression, which includes the right to freely receive, keep and distribute information and to express his or her views [2, Paragraph 100]; the right to form and join associations, political parties and other public organisations [2, Paragraph 102]; the State shall protect the freedom of previously announced peaceful meetings, street processions, and pickets [2, Paragraph 103], and employed persons have the right to a collective agreement, and the right to strike [2, Paragraph 108]. However, neither of these rights is absolute - all these may be subject to restrictions in circumstances provided for by law in order to protect the rights of other people, the democratic structure of the State, and public safety, welfare and morals [2, Paragraph 116].

This right to express views included in the Constitution may be conditionally divided into individual rights (receiving information and expressing views) and collective rights (the right of association, the right to express his or her views in an organised manner during meetings, street processions and pickets, and the right to strike). Likewise, the right associated with expressing his or her views in the field of employment and beyond it must be distinguished. These rights are systematically arranged in the Constitution: Paragraph 100 as the right to the freedom of expression in its broadest meaning; Paragraph 102 as the right to assembly and the right to association; Paragraph 103 as the right to express his or her views in public. Separately, there is the right of employed people to express their views in public, which is the right to strike.

The State protects the right of employed people to strike, which, in legal understanding, is an action associated with the freedom of assembly and an action included in the scope of the execution of the employment rights. A strike is a means of resolving a collective dispute that manifests itself in such a way that employees or a group of employees of a branch of an undertaking voluntarily, completely or in part, discontinue work in order to attain the fulfilment of demands [3, Paragraph 3, Section 1]. It can be concluded that criteria required for a strike are the following: a collective interest dispute, voluntary action, work discontinued completely or partly and there are any demands, the fulfilment of which people on strike wish to attain.

The human rights determined in the Constitution are being regulated by separate laws on the freedom of assembly and the freedom of association, and these are being regulated by the special laws and regulations. The Law on Meetings, Processions, and Pickets is one of them [5], and this is the primary legal act, by which the State guarantees and protects the freedom of peaceful assembly. The freedom of assembly can manifest itself as meetings, processions and pickets. Other state-recognised ways of assembly include public entertainment, festivity, sports and other events, and a special regulation is set therefore - the Law on Safety of Public Entertainment and Festivity Events [6]. These legal provisions are associated with the freedom of assembly. In Latvia, the freedom of association is being executed according to state-specified types - political parties, trade unions, associations of religious organisations and foundations. Any of these types of the freedom of assembly is being regulated by specific legal provision.

The Law on Meetings, Processions, and Pickets allows society expressing their views about various socially important issues of political, economic and social character, whereas the Strike Law provides for the right to active action, which is a strike, associated with the protection of collective rights of employed people. 
There is a conclusion resulting from the two legal provisions that meetings, processions and pickets are manifestations of the freedom of assembly associated with the freedom of expression and it determines that society is entitled to the right to demonstrate their position towards political, economic, and social issues. Whereas the Strike Law regulates the right of employees to discontinue work in order to attain the fulfilment of demands submitted to the employer. In Latvia, these two types of association and assembly are separated because each of them has their own restrictions and demands to be fulfilled so that the State could protect the freedom of assembly and the freedom of association guaranteed in the Constitution.

The Constitutional Court has acknowledged that the right to strike has been acknowledged as one of the fundamental rights of an individual and values of a democratic society. The right to strike is the constitutional right of employed people, and the State is obliged to ensure the implementation of this right [7, Clause 7.1]. The international legal provisions determine the right to strike. The International Covenant on Economic, Social and Cultural Rights provides for that member states undertake to promote the right to strike provided that it is exercised in conformity with the laws of the particular country [8, Claused, Article 8]. The European Social Charter provides for that states acknowledge the right of workers and employers to collective action in cases of conflicts of interest, including the right to strike, subject to obligations that might arise out of collective agreements workers previously entered into. [9, Paragraph 4, Article 6].

It unambiguously arises from these legal provisions that a member state in line with national legislation is obliged to set the right for employed people to a collective action, which is a strike.

Since 1998, when the Strike Law came into force, employees representing some sectors went on strike in Latvia, i.e., educators (in 1999), medical officers (in 2002), there was a warning strike across the railway sector (in 2001) as well as a strike of general practitioners (in 2017) [10].

Traditions of going on strike have neither been cultivated nor developed in Latvia compared with other countries [11], therefore legal framework is being applied rarely, and no problems concerning the interpretation of legal framework and utilisation in practice have been detected. However, a strike announced by Latvian general practitioners in 2017 clearly highlighted legal problems, which the author will explore in the further part of this article.

\section{Regulatory framework of strike}

The Labour Law provides for settling disputes in employment relationship [12, Chapter 8 "Deciding of Disputes"]; however, this regulation refers to individual employment agreements and does not provide for any right to strike. The Labour Dispute Law contains a reference describing a strike as a final means for the settlement of a dispute. The Strike Law provides for that a strike is a protest of a voluntary manner so that people would attain the fulfilment of their demands, discontinuing their work completely or partially [3, Clause 3, Sect. 1]. Systematically, this regulatory framework in general provides the substantive understanding of the term 'strike' - employed people may discontinue their work and go on strike in order to attain the fulfilment of their demands if none of the other types of resolving a labour dispute has led to a favourable result.

Similarly, law determines strict restrictions for the range of subjects who may announce a strike. And, these exclusively are trade unions. A trade union has been granted exclusive rights by the State: trade unions representing and protecting the labour, economic, social and professional interests of employed people, have the right to undertake collective negotiations, receive information and consult with employers, employer organisations and associations 


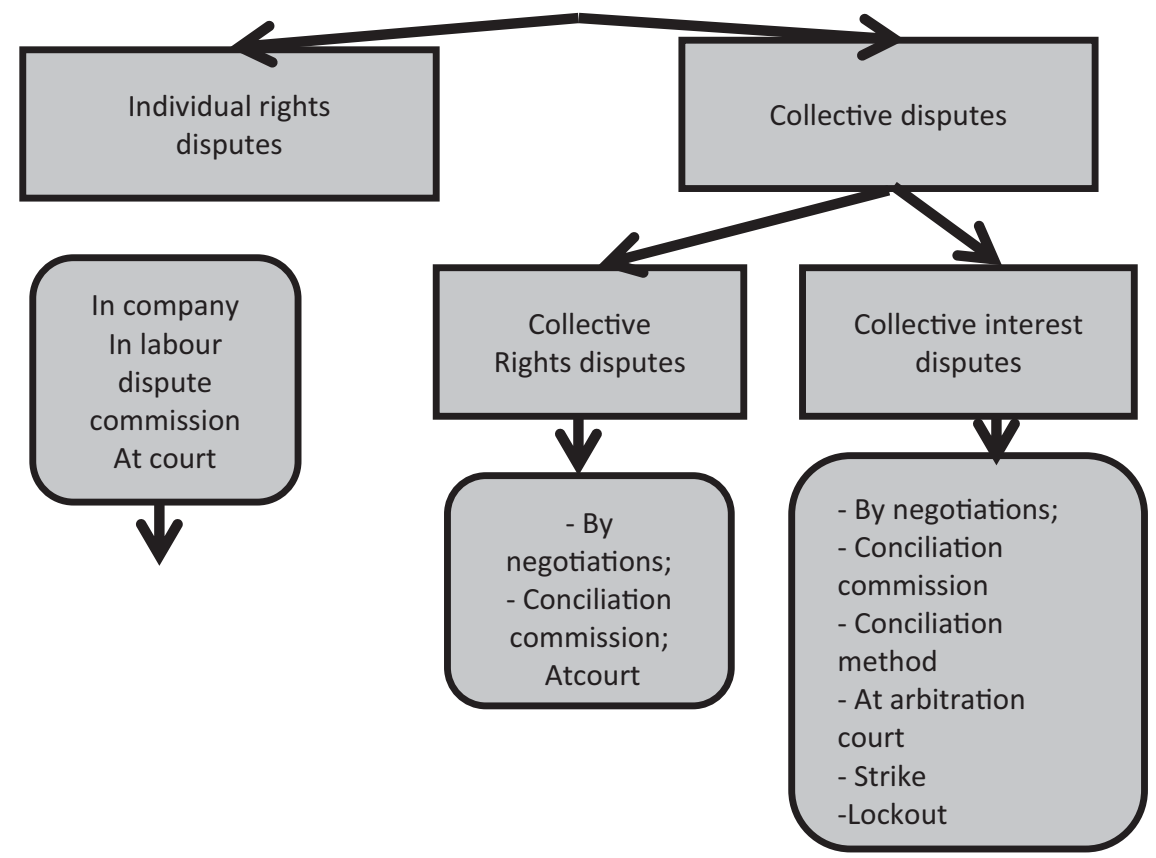

Fig. 1. Settlement of labour disputes (created by author).

thereof, to conclude collective agreement (general agreements), to announce strikes as well as to execute other rights determined in legal acts [13, Part I, Section 12].

It follows from this regulatory framework that trade unions represent labour, economic, social and professional interests of their members, and they have right to initiate bargaining and undertake negotiations with employers as well as to conclude a collective agreement. If bargaining brings no results, the State has determined the right to announce a strike as the final means for the settlement of disputes. The Law on Trade Unions is systematically adjusted to Paragraph 108 of the Constitution that determines that employed people have the right to a collective agreement and a strike. "The Labour Dispute Law and the Strike Law regulate the process of announcing a strike. The aim of the Strike Law is to correlate the right of employees to utilise a strike as a means for attaining the compliance of their interests and the fulfilment thereof with the interests of the employer. Employees are economically dependent on the employer, and there is an objective inequality between them, i.e., then employee is a weaker party in employment relations with the employer. Thus, the right to strike is an essential right of employees and their representatives in order to mitigate the inequality in powers and promote the observation of the employees' rights and well-grounded interests. A strike itself is not a fundamental instrument for attaining the observation of employees' interests during negotiations with the employers; it is a means of making the employer sit at a table and negotiate in cases when the efforts of the employees in achieving a compromise do not lead to any results." $[14,77]$.

The Labour Dispute Law divides all labour disputes into two big groups - individual disputes regarding rights and collective disputes and, in addition to it, collective disputes are divided into disputes regarding rights and disputes regarding interests (see Fig. 1).

It is a very important issue to understand who are entitled to the right to strike. i.e., who are subjects in labour disputes. The Labour Dispute Law names these subjects, and these are an employee, an employer or the representatives of either party. An employee is represented 
either by authorised representatives (trade unions) or representatives (representatives elected during the meetings of employees), but employers may be represented by an organisation of employers or associations of such organisations. The Law provides for another subject of labour disputes - the authority of the sector representatives [4, Part I, Section 2]. For example, the Ministry of Health represents medical officers, and the Ministry of Education and Science represents educators. Only the subjects specified in Section 2 of the Labour Dispute Law are entitled to use the right determined in this Law and these subjects have to execute liabilities, which have been determined.

From the Labour Dispute Law it results that labour disputes are feasible only within the framework of employment relationship [4, Section 2], but employment relationship is exclusively established by an employment agreement as a type of liabilities [12, Section 28]. Thus, the first legal problem is highlighted - in Latvia, the settlement of labour disputes has not been regulated, including the settlement with a strike, if an employment agreement between both the parties has not been concluded. And, this condition contradicts with the human rights guaranteed by the Constitution - everybody is entitled to the right to strike. There is no legal ground for restricting these human rights and determine by a law that only those employed people who have concluded employment agreements may go on strike.

Part I of Section 21 of the Labour Dispute Law and Part I of the Strike Law provide for that a strike is a collective dispute regarding interests. Thus, it has to be analysed what collective interests are, on which such a dispute may arise between the involved parties. Section 13 of the Labour Dispute Law determines subjects that may be involved in a collective dispute, and these are employees or a group of employees, or representatives of employees, whereas the other party is represented by an employer, a group of employers (2-4 employers), organisations of employers, associations of such organisations or an administrative authority of the relevant sector. The subject of the dispute is a procedure of collective bargaining, during which new working conditions or employment provisions are being set. It results from these two regulations that a collective interest dispute is a dispute arising from the involved parties determined by law about a procedure of concluding a collective agreement. And, this concerns issues discussed by the parties during bargaining.

Also Paragraph 108 of the Constitution shows that the right to strike has to be related to a collective agreement - employed people have the right to a collective agreement and the right to strike as well. The lawmaker has not separated these two rights in separate sentences or separate paragraphs; due to this, these legal provisions have to be interpreted systemically. Also Section 9 of the Labour Dispute Law defines the subject of the collective rights dispute: disputes that arise in the process of concluding, altering, terminating or fulfilling an employment agreement as well as in applying or interpreting provisions of regulatory enactments, provisions of a collective labour contract or working procedure regulations. This shows that a collective rights dispute concerns the fulfilment of effective collective agreement, interpretation and application, whereas the collective interest dispute concerns bargaining by the parties that are associated with concluding a collective agreement.

To summarise the above mentioned, collective interests are issues that the representatives of the employees wish to include into the provisions of the collective agreement (without considering that negotiations focus on altering an effective collective agreement or creating a new collective agreement) that improve the status of employees in addition to the provisions of the Labour Law or individual employment agreements.

Thus, in Latvia, the right to strike is legally regulated only for resolving those disputes concerning bargaining for concluding collective agreements that result from employment relationship. In other words, a collective interest dispute may arise only in companies in which an employment agreement is the basis for the liabilities of employed people and employers. 


\section{Practical problems of the right to strike in case of general practitioners' strike}

The above mentioned two legal problems occurred practically in 2017 when general practitioners announced a strike. General practitioners have had negotiations with the Ministry of Health for several years about the increase in funding for providing the practice of general practitioners so that general practitioners might ensure the state-guaranteed accessibility of healthcare services for patients $[12,15]$.

Negotiations with the Ministry of Health were led by the Latvian Family Physicians Association (hereinafter - Association), which according to its legal status, is an association [16]. Despite the fact that the Association is a professional association representing general practitioners, this type of association cannot be considered a trade union, which is entitled to carry on negotiations about collective interests and conclude a collective agreement. As mentioned above, in Latvia, the types of association are legally distinguished - associations and foundations, trade unions, religious organisations and political parties. Each of these types of association is being regulated by a separate law, and they are registered with the Enterprise Register of the Republic of Latvia in separate registers.

On 26 May 2017, a decision to announce a strike of general practitioners was taken during the meeting of the Association members because negotiations held with the Ministry of Health and the government have not brought any results and there are no indications that this issue concerning the increase of the sate-provided funding for practicing general practitioners will be solved in the future in order to provide healthcare services for patients.

The strike actively took place from 3 June 2017 to 18 June 2017 and went on until the end of the month, in the so-called go - slow format. In 2018, a new Healthcare Funding Law [17] and the Regulations of the Cabinet of Ministers [18] were adopted. However, these resolve the fulfilment of the demands defined in the strike of the general practitioners only partially.

The strike of the general practitioners highlighted legal problems, and they have been neither solved, nor any discussions on resolving them have been initiated. The mentioned problems are as follows: regulation for strike concerning the types of employment that are beyond employment relationship and the representation of parties in negotiations covering binding issues regarding a collective agreement.

In order to understand employment issue, it has to be indicated that in Latvia, several types of employment are valid. There is a state service, in which the administrative act is the basis for the liabilities of the parties (for example, for police officers), according to which an officer is recruited in service and appointed to a post. Law is the other type of liabilities for a state service (for example, deputies, the officers of the Corruption Prevention and Combating Bureau of Latvia). Civil liability is being established by a contract (for example, an employment agreement, company contract, transport contract etc.). Similarly, a person may be employed as a sole trader according to a procedure determined in the Commercial Law [19].

Concerning the employment of general practitioners, there are several types thereof. Firstly, general practitioners can provide services individually in the general practitioners' workplace (as sole traders) or, secondly, conclude an employment agreement with a healthcare institution (a commercial company, for example, an outpatient healthcare institution), that will provide healthcare services for patients. In the first case, general practitioners receive remuneration from patients, but in the second case they receive remuneration from their employer, which is a healthcare institution that provides healthcare services.

Irrespective of the form of employment, a workplace of a general practitioner or a commercial company has to conclude a contract governed by public law with the National 
Health Service [20, Clause 4.1] each year in order to provide a state-funded healthcare service. If a general practitioner does not conclude a contract with the State, a patient pays in full for services provided by a general practitioner.

The funding for general practitioners on the date of the strike of general practitioners was determined by Regulations No. 1529 by the Cabinet of Ministers "Funding Procedure for HealthCare" [21], which discontinued into force as of 1 January 2018. The funding determined by these Regulations was the basic demand of the general practitioners during that strike. A conclusion results from the above mentioned that only those general practitioners who have concluded an employment agreement with a healthcare institution are under employment relationship, and disputes arising from these general practitioners can be resolved according to a procedure specified in the Labour Dispute Law and the Strike Law. General practitioners did not undertake bargaining across the sector or concluding a general agreement, but they attained to achieve the increase in funding for healthcare.

The Association, not being a trade union (the representation of employees) could neither undertake negotiations with the Ministry of Health or the government within the sector, nor announce a strike under the existing regulatory framework. The Law on Trade Unions [Section 12 of the Law on Trade Unions] provides for that only trade unions are entitled to these activities. It has to be said that the Association has never indicated that it wished to conclude a collective agreement across the related sector, and instead, negotiations about bigger funding for healthcare were undertaken. Certainly, the Association as a professional authority for the representation of the members can resolve issues detected across the sector by negotiations, which is a direct proof of the freedom of association in a democratic society.

So that general practitioners could achieve amending the regulatory framework and changing the situation, they had to establish a trade union that would represent them in negotiations with the Ministry of Health about concluding a collective agreement across the sector; and in case of negative negotiations, if these parties might not come to any agreement about the provisions of the collective agreement and the balance of interests, a trade union exclusively is entitled to announce a strike. The second option for general practitioners was to announce a procession or a picket according to the procedure determined by the Law on Meetings, Processions, and Pickets and turn the attention of the whole society with the help of such a form of protest, to problems, which have grown bigger across the whole healthcare sector.

This situation clearly showed that resolving labour disputes in Latvia is neither wellconsidered nor it does cover all types of employment: the Labour Dispute Law and the Strike Law prescribe a settlement of problems regarding the parties involved in labour disputes and the object of disputes. As neither parties (not all the general practitioners are employees), nor the object (a collective agreement) complies with the Labour Dispute Law, the Latvian Family Physicians Association did not have the right to announce a strike. The Associations and Foundations Law does not give any empowerment to associations and foundations to negotiate about strike or to announce a strike.

\section{Conclusion}

The above mentioned situation, which involved general practitioners, highlighted the deficiency of the regulatory framework in Latvia so that it ensured the Constitutional and state-guaranteed rights of employed people to strike. The right to strike is given exclusively for the group of employed people which have concluded an employment agreement, and that does not comply with the principle of equality included in the Constitution. A strike can be announced only in cases when a trade union and employers cannot come to an agreement on collective interest disputes, thus this law allows trade unions utilising the final means, which is a strike. 
In order to resolve this deficiency and so that society would be provided with the rights guaranteed by the Constitution, Section 2 of the Labour Dispute Law has to be amended, in which the concept 'labour dispute' has been defined. It is offered to define the 'labour dispute' as follows: a labour dispute is any dispute that arises from employment relationship or associated with employment relationship between an employed, employed people (a group of employed people) or representatives of employed people and an employer, employers (a group of employers), an organisation of employers or an association of such organisations, or the administrative authority of the sector.

Likewise, it is necessary to amend Section 9 of the Labour Dispute Law, by expressing it as follows: a collective rights dispute is a dispute between employed people (a group of employed people) or representatives of employed people and an employer, employers (a group of employers), an organisation of employers or an association of such organisations, or the administrative authority of the sector that arise in concluding, altering, terminating or fulfilling a collective agreement, as well as applying or interpreting provisions of laws and provisions of a collective agreement or working procedure regulations.

Expanding the subjects of employment relationship from employment relationship to legal relationship of being employed, the right to strike would be expanded to people that have other civil agreement or empowerment, a type of public service liability (law or an administrative act) as the basis of the liabilities, or would grant the right to strike to a person who is a self-employed.

Currently, it is not necessary to expand the range of objects that can announce a strike. These must be the authorised representatives (trade union) of employed people. Also, the right to strike in cases when the issue of collective interests is being resolved is sufficient in order to ensure the rights to the freedom of association and the right to strike for employed people as determined by the Constitution, but at the same time, a strike is not a means that can be utilised in all cases when the interests of the parties do not coincide.

\section{References}

[1] I. Spūle, A.Tiļıla, Biedrošanās brīvība, 80 / I.Spūle, A.Tillı̧a, Freedom of Association, 80

[2] The Constitution of the Republic of Latvija (Satversme), Law of LV, LV 43 (1922)

[3] Strike Law, Law of LV, LV 130/131 (1998)

[4] Labour Dispute Law, Law of LV, LV 149 (2002)

[5] Law On Meetings, Processions, and Pickets, Law of LV, LV 31/32 (1997)

[6] Law On Safety of Public Entertainment and Festivity Events, Law of LV, LV 104 (2005)

[7] Decision by the Constitutional Court of 16 May 2007 on File No. 2006-42-01 "About the Compliance of Third Part of Paragraph 24 of the Strike Law with Paragraph 108 of the Constitution of the Republic of Latvia”, LV 81 (2007)

[8] International Covenant on Economic, Social and Cultural Rights (1976). On Internet: https://www.ohchr.org/en/professionalinterest/pages/cescr.aspx (last seen 13.12.2018.)

[9] European Social Charter, LV 183 (2001)

[10] A. Katlaps, Strike Movement in Latvia. On internet: http://providus.lv/ article/streiku-kustiba-latvija (last seen 13.12.2018)

[11] Strike. On internet: https://www.lsm.lv/temas/streiks/ (last seen 13.12.2018)

[12] Labour Law, Law of LV, LV 105 (2001)

[13] Law on Trade Unions: LV Law. Latvijas Vēstnesis No. 60, 25.03.2014

[14] N. Mickeviča, K. Rācenājs, Law on Trade Unions with Comments, 160 
[15] S. Olsena, First Strike of Latvian General Practitioners: Practically, Legally, Illegitimately, JV 41 10-18 (2017)

[16] Associations and Foundations Law, Law of LV, LV 161 (2003)

[17] Veselības aprūpes finansēšanas likums, Law of LV, LV 259 (2017) / Law on Healthcare Funding, Law of LV, LV 259 (2017)

[18] Procedure for Organisation and Remuneration for Healthcare Services, Regulations of the Cabinet of Ministers No. 555, LV 176 (2018)

[19] The Commercial Law, Law of LV, LV 158/160 (2000)

[20] Statute of the National Health Service, Regulations of the Cabinet of Ministers No. 850, LV 178 (2011)

[21] Procedure for Funding Healthcare, Regulations of the Cabinet of Ministers No. 1529. Discontinued in force as of 1 January 2018 